\title{
THE CORRELATION BETWEEN CHATTING ONLINE AND STUDENTS' SPEAKING ACHIEVEMENT
}

\author{
Essa Widya Pangestika ${ }^{1}$, Sri Nariah ${ }^{2}$ \\ ${ }^{1}$ IKIP Siliwangi \\ ${ }^{2}$ IKIP Siliwangi \\ ${ }^{1}$ widyaessa@gmail.com, ${ }^{2}$ nariahsri@gmail.com
}

\begin{abstract}
The aim of this research is to figure out the correlation between chatting online and students' speaking achievement. The method of this research was correlation method. The researchers used this research because they wanted to find out the degree of relationship students chatting online and their speaking skill achievement in English Education Department of IKIP Siliwangi in the academic year 2015. The data were gathered from the questionnaires and speaking tests, then were analyzed by Spearman Rank in SPSS V.23. The result showed that the score of Spearman Rank test is 0.299. It was defined that there is low correlation between two variables. In other words, there was no significance correlation between students chatting online and their speaking achievement.
\end{abstract}

Keywords: Correlation, Chatting Online, Speaking Achievement

\section{INTRODUCTION}

To communicate with other people, people need mastering speaking skill, as well as to make the communication more clearly and maintain social relationship."The common communication happened in the society is interpersonal communication where someone speaks to someone else, thus there are two people involved in this communication, speaker and the hearer" (Rehana, 2008). Through speaking people can do everything for social life, it can make them easier to communicate each other. Communication is an essential need for human being, however nowadays when people want to communicate they do not have to meet face to face but can go through the online application.

Communicating via online, or in this study reffered as online chatting, has become one of the ways of the communication that mostly students' do. (Sativa, 2010) has stated "the online media becomes the alternative to fulfill the information needs of the community. By using online media, the people focus on which information will be read or looked for. And then they can log in and $\log$ out into this media to choose which information they want". And as the students of English Department, they are considered to speak English frequently in their online chatting. Moreover when it is taken with people from other countries.

Based on the explanation above, this study is intended to find out whether there is a correlation between students' chatting online and their speaking achievement.

\section{METHOD}

This research uses correlational method. "Correlational research is one of descriptive research designs used to measure the relationship between two or more continuous variables"(Latief, 2011). It is because this study focuses on finding of relationship students' chatting online and their speaking achievement of the sixth semester students of college of English Education of 
IKIP Siliwangi in the Academic year 2015. The sample is 36 students of A2 2015 class. In collecting the data, the questionnaire and speaking tests is applied. In collecting the data, the questionnaire and speaking tests is applied. They are administered to find out the information related to the students chatting online and their ability in speaking.

The data from questionnaire are developed using Likert-scale. Based on (McMillan \& Schumacher, 2001) a true Likert scale is one in which the stem includes a value or direction and the respondent indicate agreement or disagreement with the statement.

Table 1

An example of the likert-scale

\begin{tabular}{llllll}
\hline \multicolumn{1}{c}{ Statements } & $\begin{array}{l}\text { Strongly } \\
\text { Disagree }\end{array}$ & Disagree & Less Agree & Agree & Strongly Agree \\
\hline $\begin{array}{l}\text { I like to use } \\
\text { online media }\end{array}$ & & & & \\
\hline
\end{tabular}

Notes :

The table on the first column is the statement, and in the second column is the scale from strongly disagree, disagree, partly agree, agree, and the last strongly agree. Then, to score the likert scale, each answer were labeled with value from 1 to 5.

To find out the answer of the questionnaire, it employs the formula below :

$$
\mathrm{N}=\frac{F}{m} \times 100
$$

Notes :

$\mathrm{N}=$ Total Answer

$\mathrm{F}=$ The total value of answer

$\mathrm{m}=$ Maximum Score

The researchers assess the students speaking skill ability based on oral proficiency scoring categories by (Brown H. Douglas, 2000). To process the score in speaking skill test, it employs the formula below :

$$
\mathrm{N}=\frac{F}{m} \times 100
$$

Notes :

$\mathrm{N}=$ Total Answer

$\mathrm{F}=$ The total value of answer

$\mathrm{m}=$ Maximum Score

From the calculation of the above formula, the value of questionnaire and speaking test will be analyzed using pearson product moment or spearman rank in SPSS V.23. 


\section{RESULTS AND DISCUSSION}

\section{Results}

The researcher had given questionnaires which consisted of 10 (ten) items to the students. It was used by the researcher to get students' opinions about how often the students chatting online using English, and for the speaking achievement as explained in the previous part the data come from the lecturer. In order to find out the significant correlation between students' chatting online and their achievement in speaking skill, the researcher presented both of the results in the following table.

Table 2

The score of The Questionnaire and Speaking Skill

\begin{tabular}{clcc}
\hline No & \multicolumn{1}{c}{ Initial } & X & Y \\
\hline $\mathbf{1}$ & RM & 70 & 64 \\
\hline $\mathbf{2}$ & ASY & 60 & 60 \\
\hline $\mathbf{3}$ & NAP & 54 & 60 \\
\hline $\mathbf{4}$ & AMH & 66 & 52 \\
\hline $\mathbf{5}$ & ASN & 62 & 64 \\
\hline $\mathbf{6}$ & TM & 64 & 52 \\
\hline $\mathbf{7}$ & RP & 56 & 60 \\
\hline $\mathbf{8}$ & BV & 58 & 48 \\
\hline $\mathbf{9}$ & YAS & 66 & 48 \\
\hline $\mathbf{1 0}$ & SY & 72 & 73 \\
\hline $\mathbf{1 1}$ & DSG & 66 & 44 \\
\hline $\mathbf{1 2}$ & AFY & 66 & 60 \\
\hline $\mathbf{1 3}$ & MAS & 72 & 52 \\
\hline $\mathbf{1 4}$ & EIL & 64 & 60 \\
\hline $\mathbf{1 5}$ & FA & 66 & 60 \\
\hline $\mathbf{1 6}$ & GP & 66 & 52 \\
\hline $\mathbf{1 7}$ & EDH & 68 & 60 \\
\hline $\mathbf{1 8}$ & MNM & 64 & 44 \\
\hline $\mathbf{1 9}$ & NFP & 62 & 60 \\
\hline $\mathbf{2 0}$ & IA & 60 & 56 \\
\hline $\mathbf{2 1}$ & MD & 66 & 44 \\
\hline $\mathbf{2 2}$ & RE & 68 & 70 \\
\hline $\mathbf{2 3}$ & RPA & 68 & 60 \\
\hline $\mathbf{2 4}$ & NH & 62 & 52 \\
\hline $\mathbf{2 5}$ & ED & 82 & 80 \\
\hline $\mathbf{2 6}$ & AP & 64 & 64 \\
\hline $\mathbf{2 7}$ & YS & 68 & 56 \\
\hline $\mathbf{2 8}$ & YNT & 68 & 52 \\
\hline $\mathbf{2 9}$ & WPZ & 66 & 72 \\
\hline $\mathbf{3 0}$ & IH & 72 & 56 \\
\hline $\mathbf{3 1}$ & YDJ & 80 & 72 \\
\hline $\mathbf{3 2}$ & DF & 64 & 44 \\
\hline $\mathbf{3 3}$ & NS & 64 & 60 \\
\hline $\mathbf{3 4}$ & KF & 70 & 72 \\
\hline & & & \\
\hline
\end{tabular}




\begin{tabular}{llll}
\hline 35 & MN & 66 & 64 \\
\hline $\mathbf{3 6}$ & GI & 64 & 60 \\
\hline
\end{tabular}

From the table above, the mean for variable $\mathrm{X}$ was 65.94 and the mean for variable $\mathrm{Y}$ was 58.52. Before conducting correlation analysis the test should be done is normality test, which aims to know the distribution of the data, it is normal or not. The following table shows the result of normality test :

Table 3

The Result of Test Normality

Tests of Normality

\begin{tabular}{|l|r|r|r|r|r|r|}
\hline & \multicolumn{3}{|c|}{ Kolmogorov-Smirnova } & \multicolumn{3}{c|}{ Shapiro-Wilk } \\
\cline { 2 - 7 } & Statistic & \multicolumn{1}{|c|}{ Df } & \multicolumn{1}{c|}{ Sig. } & Statistic & \multicolumn{1}{c|}{ Df } & \multicolumn{1}{c|}{ Sig. } \\
\hline ChatingOnline & .163 & 36 & .017 & .929 & 36 & .023 \\
Speaking & .157 & 36 & .025 & .949 & 36 & .098 \\
\hline
\end{tabular}

a. Lilliefors Significance Correction

From the output of normality test above, it can be read that the distribution of the data is not normal because both of them showed the sig less than 0.05 it means the distribution of the data is not normal. Hence, the gained data should be analyzed by Spearman Rank in SPSS V.23 to test the correlation. The Result is in following table :

Table 4

The Result of Correlation Test

\begin{tabular}{|rll|r|r|}
\hline & & ChatingOnline & Speaking \\
\hline Spearman's rho & ChatingOnline & Correlation Coefficient & 1.000 & .299 \\
& & Sig. (2-tailed) &. & .077 \\
& $\mathrm{~N}$ & 36 & 36 \\
\cline { 2 - 5 } & Correlation Coefficient & .299 & 1.000 \\
& Sig. (2-tailed) & .077 &. \\
& $\mathrm{~N}$ & 36 & 36 \\
& & & & 36 \\
& & &
\end{tabular}

From the correlations test above, it can be seen that the correlation coefficient between two variables is 0.299 according to (Best \& Khan, 2006) it is in the range $0.20-0.399$, it means Spearman Rank Correlation is low. Meanwhile the result of sig (2-tailed) is 0.077 higher than 0.05 it means that the Null Hypotheses (Ho) is accepted, in other words there is no significant correlation between students' chatting online and their speaking skill. 


\section{Discussion}

As described in previous section, the objective of this research is to find out the correlation between students' chatting online and their speaking skill achievement. To answer the question the researchers gave a questionnaire and speaking test to students. The result showed that there was no significant correlation between students' chatting online and their speaking skill achievement.

The result above also related with the research conducted by (Astiyani, 2015). She mentioned that the null hypotheses of the research of the fourth semester students of the College of Language of Sultan Agung Islamic University Semarang was accepted. In other words, she also discovered that there was no correlation between online chatting and the students' speaking ability.

\section{CONCLUSION}

Based on the results as already discussed in previous part, it can be concluded that the correlation between students' chatting online and their speaking achievement of the sixth semester students of IKIP Siliwangi is in low correlation. It can be seen from the computation of the coefficient correlation by using Spearman Rank in SPSS V.23 the result is 0.299 and sig 2 (tailed) is 0.777 higher than 0.05 which means there is no significant correlation between students' chatting online and speaking skill achievement. It means the frequencies of students' chatting online is not affected to their speaking ability, in other words this research have a negative correlation.

\section{ACKNOWLEDGMENTS}

Alhamdulillahirabbil 'alamin, praise to Allah who has enabled the researchers to finish this journal. Peace and salutations are always for Muhammad SAW. During completing the journal the researchers obtained many help, suggestions and motivations from many people. For that reason, the researcher would like to express his gratitude to, Dr. H. Heris Hendriana, M.Pd as head of IKIP Siliwangi, Irma Savitri Sadikin, S.Pd., M.Pd as head of English Education Study Program, and Siska Rizkiani, M. Pd as our supervisor, thanks for careful guidance to accomplish the journal.

\section{REFERENCES}

Astiyani, T. (2015). The Correlation Study Of Online Chatting And Students' Speaking Ability. (The Case Of The Fourth Semester Students Of College Of Language Of Sultan Agung Islamic University Semarang In The Academic Year Of 2014/2015.

Best, J. W., \& Khan, J. V. (2006). Research In Education. New York: Pearson Education Inc. Brown H. Douglas. (2000). Teaching By Principles. Teaching By Principles An Interactive Approach To Language Pedagogy. San Fransisco: Longman.

Latief, M. A. (2011). Research Methods On Language Learning; An Introduction. Malang: Um Press.

Mcmillan, J. H., \& Schumacher, S. (2001). Research In Education. A Conceptual Introduction. London: Addison Wisley Longman, Inc.

Rehana. (2008). The Application Of Students Spoken Feedback To Improve The Speaking Accuracy. Makassar.

Sativa, D. (2010). Media Online Dan Pemenuhan Kebutuhan Informasi. Surakarta. 